\title{
ACCESS TO JUSTICE TERHADAP PERLINDUNGAN PEKERJA MIGRAN DALAM BANTUAN PERWAKILAN KEDUTAAN DAN KONSULAT
}

\author{
Sandy Kurnia Christmas ${ }^{1}$
}

\begin{abstract}
Access to justice by the rights of migrant workers in essence needs to be improved both in terms of transparency and accountability of protection. In realizing the protection of migrant workers abroad, the role of embassies and consulates is a very important role. The form of state responsibility in providing protection for the rights of migrant workers by the help of representatives of embassies and consulates, as well as how the effectiveness of the assistance is a problem that will be studied in this study. The research method used is the juridical-normative method, which is then reviewed with a conceptual approach and a case approach. This study aims to ascertain whether legal assistance carried out by the Embassies and Consulates has been running properly in accordance with the legal rules that pay attention to the rights of migrant workers who have a justice perspective in human rights or not. The results of this study recommend a more efficient standard procedure for protection procedures, and ensure that there is transparency and fairness on target, so that protection can be received by all migrant workers.
\end{abstract}

Keywords : access to justice, embassies and consulates, migrant workers, protection.

\begin{abstract}
Abstrak
Akses terhadap keadilan oleh hak-hak pekerja migran pada hakekatnya perlu ditingkatkan baik dalam transparansi maupun akuntabilitas perlindungannya. Dalam mewujudkan perlindungan pekerja migran di luar negeri, peran Kedutaan dan Konsulat menjadi peran yang sangat penting. Bagaimana bentuk Tanggung Jawab negara dalam memberikan perlindungan hak pekerja migran oleh bantuan perwakilan Kedutaan dan Konsulat, serta bagaimana efektifitas bantuan tersebut merupakan permasalahan yang akan dikaji dalam penelitian ini. Metode penelitian yang digunakan yaitu metode yuridis-normatif, yang kemudian dikaji dengan pendekatan konseptual dan pendekatan kasus. Penelitian ini bertujuan untuk memastikan apakah bantuan hukum yang dilakukan oleh Kedutaan dan Konsulat sudah berjalan semestinya sesuai dengan aturan hukum yang memperhatikan hak pekerja migran yang berperspektif keadilan dalam hak asasi manusia atau belum. Hasil dari penelitian ini merekomendasikan mekanisme prosedur standar perlindungan yang lebih efisien, serta menjamin adanya transparansi dan keadilan yang tepat sasaran, sehingga perlindungan dapat diterima semua pekerja migran.
\end{abstract}

Kata Kunci: akses terhadap keadilan, kedutaan dan konsulat, perlindungan, tenaga kerja migran.

\footnotetext{
${ }^{1}$ Magister Ilmu Hukum, Fakultas Hukum, Universitas Diponegoro, Jln. Imam Bardjo, Pleburan, Semarang, Jawa Tengah, Indonesia, email : ch.sandykurnia@gmail.com, Telp. 082350044509
} 


\section{Pendahuluan}

Permasalahan mengenai adanya keterbatasan lapangan pekerjaan dan kondisi perekonomian yang kurang menarik di negara asal, serta adanya pengaruh negara tujuan yang memiliki standar upah yang besar menjadi pemicu terjadinya mobilitas tenaga kerja secara internasional melakukan migrasi ke negara lain untuk mencari pekerjaan. Terjadinya migrasi merupakan langkah alternatif yang diambil oleh individu sebagai upaya untuk mengubah kualitas kehidupannya atas keterbatasan ekonomi serta distribusi kesempatan di tingkat domestik.

Adanya migrasi tenaga kerja Indonesia ke luar negeri yang sudah berlangsung sejak tahun 1970-an dan terus mengalami peningkatan dalam jumlahnya, dimana meningkatnya angka tenaga kerja migran Indonesia ke luar negeri tidak dapat dipisahkan dari kondisi pertumbuhan angkatan kerja dan ketersediaan lapangan pekerjaan domestik ${ }^{2}$. Kecenderungan tenaga kerja Indonesia untuk bekerja di luar negeri selain adanya perolehan upah yang besar, para tenaga kerja Indonesia ini juga diberikan bekal seperti keterampilan dan keahlian, meskipun para tenaga kerja migra Indonesia yang bekerja diluar negeri rata-rata memiliki persoalan

2 Syamsul Hadi. 2008. "Sekuritisasi dan Upaya Peningkatan Perlindungan Terhadap Tenaga Kerja Indonesia", Jurnal Hukum Internasional Labour Law, 5(4) : hlm.745. pendidikan yang kurang memadai. ${ }^{3}$

Terjadinya mobilitas tenaga kerja Indonesia yang bermigrasi mencari pekerjaan diluar negeri menjadi suatu trend dikalangan para pencari kerja. Namun terjadinya mobilitas pekerja migran ini menimbulkan banyaknya kasus yang menimpa para pekerja migran, sehingga dibutuhkan suatu perlindungan untuk mengatasi permasalahan mereka. Terjadinya permasalahan tersebut sebagian besar dikarenakan minimnya pengetahun para pekerja migran untuk mengakses hak-hak mereka. Kurangnya perhatian dan perlindungan dari negara pengirim dikarenakan perhatian dari negara pengirim hanya berfokus pada permasalahan tenaga kerja didalam negeri, dan cenderung menutup akses publik jika terjadi adanya pelanggaran oleh pekerja migran di negara tujuan, sehingga hal ini menimbulkan dilema para pekerja migran tersebut untuk memperjuangkan hak-hak mereka. ${ }^{4}$ Perlindungan yang dimaksud adalah upaya untuk menjamin pemenuhan hak-hak pekerja migran dengan baik pada masa pra-penempatan, masa penempatan, serta masa purna penempatan.

3 Haning Romdiati. 2012. "Migrasi Tenaga Kerja Indonesia Dari Kabupaten Tulungagung : Kecenderungan dan Arah Migrasi, serta Remitansi", Jurnal Kependudukan Indonesia, (7(2) : hlm.28.

4 Arpangi. 2016. "Perlindungan Hukum Terhadap tenaga Kerja Indonesia Di Luar Negeri”, Jurnal Pembaharuan Hukum, 3(1) : hlm.151. 
Pada kasus yang dihadapi pekerja migran Indonesia di Malaysia tahun 2019, terdapat delapan pekerja migran Indonesia yang dikriminalisasi, dimana justru mereka menjadi korban karena tidak mendapatkan perlakuan yang layak sebagai pekerja migran, dan sebagian dari mereka bahkan menjadi korban perdagangan orang. Berdasarkan data yang diterima melalui pengaduan ke Migrant Care Malaysia pada akhir November 2019, terdapat delapan perempuan pekerja migran Indonesia yang bekerja di malaysia dengan kondisi kerja yang tidak layak. ${ }^{5} \mathrm{Hal}$ tersebut juga ditambah beberapa kasus dugaan pelanggaran kontrak kerja yang dilakukan perusahaan, dimana selain penempatan kerja, pembayaran, serta upah yang tidak sesuai dengan kontrak kerja, terjadi pula penahanan dokumen serta pembatasan akses komunikasi. Menurut wahyu Susilo, selaku Direktur Eksekutif Migrant Care, mengatakan "Seharusnya kasus yang dihadapi pekerja migran Indonesia, ada peran aktif kedutaan besar Ri di negara terkait. Tapi sepertinya KBRI sangat pasif, dan tidak melakukan perlawanan apa-apa."6

Berdasarkan kasus tersebut, ketika hak-hak pekerja migran ini dilanggar,

\footnotetext{
${ }^{5}$ Sonya Hellen Sinombor. 2020. "Kedutaan Besar RI Diminta Pro-Aktif Lindungi Buruh Migran", Available from https://bebas.kompas.id/baca/humaniora/dikbud/ 2020/01/23/kedutaan-besar-ri-diminta-pro-aktif-lin dungi-buruh-migran/. (Accessed February 20, 2020)

6 Ibid.

mereka kesulitan untuk menuntut atau mengakses hak-hak mereka. Beberapa kasus yang sering tejadi adalah pekerja migran terkadang mengalami kesulitan dalam mengakses hak-hak mereka setelah ditempatkan (diperkerjakan) ke luar negeri. Hal ini memberikan pandangan bahwa akses terhadap keadilan di negara asal juga merupakan perkara yang penting. Banyak kerugian yang dialami oleh para buruh migran selama berada di luar negeri dapat dikaitkan dengan kurangnya transparansi dan akuntabilitas dalam proses perekrutan yang diprivatisasi di negara asal serta tidak tersedianya pelatihan dan informasi berbasis hak yang memadai bagi calon TKI sebelum keberangkatan. Permasalahan ini disebabkan karena lemahnya kebijakan sosial, dimana kurang efektif dan kreatifnya pengawasan pemerintah terhadap para tenaga kerja migran. ${ }^{7}$

Berkaitan dalam akses mendapatkan bantuan hukum di Kedutaan dan Konsulat diatur dalam Pasal 23 ICMRW 1990, dimana bantuan ini memiliki tugas untuk meningkatkan sumberdaya dan pelatihan untuk : memberikan bantuan hukum yang kompeten bagi para pekerja di negara tujuan; melakukan evaluasi yang lebih ketat terhadap agen tenaga kerja

\footnotetext{
7 Tri Lisiani Prihatinah, Noor Asyik, dan Kartono. 2012. "Kendala Perlindungan Hukum Terhadap Buruh Migran di Kabupaten Cilacap", Jurnal Dinamika Hukum, 12(2) : hlm.313.
} 
maupun pihak majikan di negara tujuan dan memberikan informasi yang tersedia bagi para pekerja sebelum keberangkatan; memberikan saran kepada pekerja tentang proses ganti rugi di Indonesia, serta memberikan nasehat dan membantu mereka untuk mendapatkan bukti yang diperlukan ketika masih berada di luar negeri. Proses penanganan pengaduan di kedutaan juga harus lebih standar, transparan, responsif, dan secara geografis dapat diakses. Hal ini mendapatkan sejumlah kritikan dari para pekerja migran, dimana dikatakan kurangnya sumberdaya di kedutaan dan konsulat, kurangnya keahlian tentang hukum dan prosedur di Indonesia dan di negara tujuan yang relevan, serta kurangnya transparansi prosedur standar.

Peningkatan akses terhadap keadilan (Access to Justice) setidaknya membutuhkan sebuah reformasi mekanisme. Peningkatan ini membutuhkan suatu upaya pemahaman dan penyadaran hak asasi manusia dalam rangka pemenuhan, perlindungan dan penegakan HAM adalah suatu pekerjaan berat yang membutuhkan proses panjang, sehingga perlu ditetapkan program konkret secara terencana dan berkesinambungan. Hal ini sudah dilakukan oleh pemerintah melalui Program Rencana Aksi Nasional
Hak Asasi Manusia (RANHAM). ${ }^{8}$

Berkaitan dengan perlindungan terhadap pekerja migran dalam bantuan oleh kedutaan dan konsulat, hal ini belum pernah dilakukan penelitian. Dalam penelitian oleh Hidayat (2017) membahas bentuk perlindungan tenaga kerja migran di aspek hak sipil dan politiknya diluar negeri. Penelitian oleh Arpangi (2016) membahas perlindungan hukum terhadap tenaga kerja Indonesia di luar negeri yang dibahas secara umum. Penelitian oleh Riri Anggriani (2017) membahas perlindungan hukum bagi irregular migrant workes di kawasan asia tenggara. Sedangkan penelitian oleh Rizky Dian Bareta (2018) membahas poltik hukum dalam perlindungan tenaga kerja Indonesia fase purna bekerja. Sehingga berdasarkan uraian diatas, maka dapat dirumuskan dua masalah yaitu : (1) Bagaimana bentuk access to justice tanggung jawab negara dalam memberikan perlindungan hak tenaga kerja migran oleh bantuan perwakilan Kedutaan dan Konsulat? ; Bagaimana efektivitas perlindungan yang diberikan oleh Kedutaan dan Konsulat terhadap akses bantuan hak pekerja migran?

${ }^{8}$ Rahadi Wasi Bintoro, Riris Ardhanariswari, dan Rahman Permana. 2008. "Implementasi UU No.13 Tahun 2003 Tentang Ketenagakerjaan Bagi Tenaga Kerja Perempuan di Kabupaten Purbalingga", Jurnal Dinamika Hukum, 8(3) : hlm.231. 


\section{Metode}

Pembahasan

mengenai perlindungan hak pekerja migran oleh bantuan Kedutaan dan Konsulat ini dikaji menggunakan metode penelitian yuridis normatif, yang kemudian dikaji dengan Pendekatan Konseptual (Conseptual Approach) serta dalam Pendekatan Studi Kasus (Case Approach), dimana penelitian ini dikaitkan dalam kaidah-kaidah atau norma dalam hukum didalam pendekatan hukum doktrinal. ${ }^{9}$ Pada penelitian hukum ini, kajian dilakukan dengan menggunakan analisa berdasarkan sumber-sumber hukum seperti bahan hukum, sumber hukum nasional maupun internasional, serta sumber hukum terkait yang terdapat didalam jurnal maupun sumber online.

Kajian penelitian dengan menggunakan sumber hukum nasional dalam penelitian ini dikaji dengan menggunakan beberapa undang-undang hukum nasional Republik Indonesia, seperti UUD NRI 1945, UU No.39 Tahun 1999 tentang HAM, serta dalam UU No.18 Tahun 2017 ttg Perlindungan Pekerja Migran Indonesia. Sedangkan kajian menggunakan sumber hukum internasional, digunakan beberapa perjanjian internasional seperti International Convention on the Protection of the rights of All Migrant

9 Jhonny Ibrahim. 2006. Teori dan Metodologi Penelitian Hukum Normatif. Malang : Bayumedia Publishing, hlm.23.

148
Workers and Members of Their Family 1990), C143 - Migrant Workers (Supplementary Provision) Convention 1975 / Convention Concerning Migrations in Abusive Conditions and the Promotion of Equality of Opportunity and Treatment of Migrant Workers, serta C097 - Migrant for Employment Convention (Revised) 1947 / Convention Concerning Migration for Employment (Revised 1949)."

\section{Analisis dan Pembahasan}

\section{A. Access to Justice Perlindungan Hak Tenaga Kerja Migran Indonesia dari Bantuan Perwakilan Kedutaan dan Konsulat}

Upaya melakukan perlindungan terhadap pekerja migran di luar negeri dilakukan oleh Pemerintah Indonesia disetiap prosesnya, baik sejak proses rekrutmen, selama bekerja, maupun hingga pemulangan ke tanah air, sesuai dalam ketentuan pada Pasal 77 UU No. 39 Tahun 2004. Salah satu bentuk upaya perlindungannya kepada tenaga kerja migran di Indonesia, yaitu telah mendirikan layanan dalam misi luar negeri yang menitik beratkan kepada perlindungan terhadap pekerja migran. Bahkan didalam perjanjian kerja mensyaratkan bahwa setiap perselisihan antara pekerja migrandan majikannya diselesaikan secara damai dengan bantuan kedutaan. Perlindungan ini merupakan wewenang yang diberikan 
oleh Hukum Internasional kepada negara-negara pengirim, artinya negara pengirim boleh melakukan perlindungan terhadap warga negaranya yang berada di negara tersebut. ${ }^{10}$ Artinya bahwa negara menjamin perlindungan hak-hak segenap warga negara baik didalam maupun diluar negeri. ${ }^{11}$

Berdasarkan Teori Perlindungan, mengatakan bahwa hukum dapat difungsikan untuk mewujudkan perlindungan yang sifatnya tidak sekedar adaptif dan fleksibel, melainkan juga prediktif dan antisipatif. ${ }^{12}$ Perlindungan, pemenuhan, dan penegakan HAM yang dilakukan oleh negara-negara ditandai dengan keberhasilan masyarakat internasional delam memperjuangkan pengakuan, penghormatan, dan penegakan nilai-nilai HAM dalam instrumen-instrumen HAM. ${ }^{13}$

Berdasarkan UU No.18 Tahun 2017 tentang Perlindungan Pekerja Migran Indonesia, terdapat didalam Pasal 6 ayat (1) huruf (g) menyebutkan bahwa pekerja migran memperoleh perlindungan dan bantuan hukum atas

10 Peni Setyorini. 2010. "Perlindungan Tenaga Kerja Indonesia (TKI) Di Luar Negeri Oleh Perwakilan Republik Indonesia", Masalah-Masalah Hukum, 39(1) : hlm.66.

11 Aga Natalis \& Budi Ispriyarso. 2018. "Politik Hukum Perlindungan Pekerja Migran Perempuan di Indonesia", Pandecta Research Law Journal, 13(2) : hlm.113.

12 Lili Rasjidi \& Wysa Putra. 2003. Hukum Sebagai Suatu Sistem. Bandung : Remaja Rusdakarya.

${ }^{13}$ Riri Anggriani. (2017). "Perlindungan Hukum Bagi Irregular Migrant Workers Indoneisa Di Kawasan Asia Tenggara (Dalam perspektif Hukum HAM Internasional)", Jurnal Yuridika. 32(2) : hlm.321. tindakan yang merendahkan harkat dan martabat sesuai dengan ketentuan peraturan perundang-undangan di Indonesia dan di negara tujuan penempatan. Pasal ini mempunyai keterkaitan dengan pembahasan dalam Konferensi Tingkat Tinggi (KTT) ASEAN Ke-31 di Manila yang kemudian menyepakati "ASEAN Consensus on the Promotion and Protection of the Rights of Migrant Workers", yang berbunyi, "Hak mendapatkan bantuan dari perwakilan pemerintah di negara penempatan". Hal ini konsisten sesuai dengan Pasal 23 Konvensi Internasional tentang Perlindungan Hak-Hak Seluruh Pekerja Migran dan Anggota Keluarganya (International Convention on the Protection of the rights of All Migrant Workers and Members of Their Family 1990), yang berbunyi, "Para Pekerja migran dan anggota keluarganya harus memiliki hak buntuk memperoleh pilihan meminta perlindungan dan bantuan pejabat konsuler atau diplomatik dari Negara asalnya atau Negara yang mewakili kepentingan Negara tersebut, apabila hak-hak yang diakui dalam Konvensi ini dilanggar..." Hal ini memiliki perspektif bahwa jaminan atas hak mendapatkan bantuan hukum di lembaga kedutaan ataupun konsulat dijamin berdasarkan hukum internasional dan hukum nasional. Setelah ratifikasi International Convention on The Protection of The 
Rights of All Migrant Workers and Members of Their Families melalui Undang-Undang Nomor 6 Tahun 2012 tentang Pengesahan International Convention on The Protection of The Rights of All Migrant Workers and Members of Their Families (Konvensi Internasional Mengenai Perlindungan Hak-Hak Seluruh Pekerja Migran dan Anggota Keluarganya), politik hukum Indonesia lebih mengarah pada substansi perlindungan TKI itu sendiri. ${ }^{14}$ Adanya kerjasama antar negara-negara, baik regional maupun multilateral ini diperlukan untuk memfasilitasi perkembangan mobilitas pekerja migran, terutama Indonesia yang berada di kawasan ASEAN. ${ }^{15}$

Upaya mendapatkan akses terhadap keadilan (access to justice) oleh pekerja migran oleh Indonesia dalam reformasi hukumnya melakukan langkah meratifikasi Konvensi PBB tentang Buruh Migran (UN Convention on the Protection of the Rights of All Migrant Workers and Member of Their Families). Adapun didalam Kedutaan didalamnya terdapat Divisi Perlindungan Warga Negara yang merupakan divisi yang bertugas untuk melindungi dan membantu semua warga negara

14 Rizky Dian Bareta dan Budi Ispriyarso. 2018. "Politik Hukum Perlindungan tenaga Kerja Indonesia Fase Purna Bekerja", Kanun Jurnal IImu Hukum. 20(1) : hlm.173.

15 Yuni Sudarwati. 2014. "Upaya Indonesia Menghadapi Migrasi Tenaga Kerja Dalam Komunitas Ekonomi Asean (KEA) 2015", Jurnal Ekonomi \& Kebijakan Publilk, 5(1) : hlm.19.

$\square 150$
Indonesia yang berada di luar negeri. Pasal 78 ayat (1) menyatakan bahwa "Perwakilan Republik Indonesia memberikan perlindungan terhadap TKI di luar negeri sesuai dengan peraturan perundang-undangan serta hukum dan kebiasaan internasional." Hal ini dapat disimpulkan secara hukum mereka memiliki fungsi untuk melindungi warga negara dan berbagai kepentingan negaranya di negara akreditasi, termasuk perlindungan terhadap tenaga kerja migran. ${ }^{16}$

Bantuan dari Kedutaan dan Konsulat ini merupakan suatu bantuan terhadap akses-akses bantuan, seperti ganti rugi atau memperoleh bukti ketika pekerja berada diluar negeri, dan setelah kembali pulang. Kedutaan dan Konsulat memiliki tanggung jawab terhadap hak-hak pekerja migran dalam upaya meningkatkan sumber daya dan pelatihan untuk memberikan bantuan hukum yang kompeten bagi para pekerja di negara tujuan; melakukan evaluasi yang lebih ketat terhadap agen tenaga kerja maupun pihak majikan di negara tujuan dan memberikan informasi yang tersedia bagi para pekerja sebelum keberangkatan; memberikan saran kepada pekerja tentang proses ganti rugi di Indonesia, serta memberikan nasehat dan membantu mereka untuk

16 Boer Mauna. 2000. Hukum Internasional : Pengertian, Peranan, dan Fungsi Dalam Era Dinamika Global. Bandung : Alumni. 
mendapatkan bukti yang diperlukan ketika masih berada di luar negeri. Proses penanganan pengaduan di kedutaan juga harus lebih standar, transparan, responsif, dan secara geografis dapat diakses. Upaya menjalankan tugas dan fungsinya dalam melindungi, diartikan bahwa seorang duta wajib melindungi pribadi, harta benda, kepentingan-kepentingan warga negaranya yang berada diluar negeri.

Setelah adanya Instruksi Presiden No.6 Tahun 2006 tentang Kebijakan Reformasi Sistem Penempatan dan Perlindungan Tenaga Kerja Indonesia, Menteri Luar Negeri dan Menteri Tenaga Kerja dalam hal ini mengadopsi peraturan yang menempatkan stafnya di kedutaan sebagai atase tenaga kerja untuk melakukan kegiatan yang berhubungan dengan ketenagakerjaan. Adapun Kantor Atase Tenaga Kerja dalam Perwakilan Republik Indonesia memliki fungsi dalam perlindungan khusus bagi tenaga kerja migran, yaitu:

1. Fasilitasi dan medias penyelesaian perselisihan atau sengketa antara TKI dan Pengguna di negara penempatan; dan

2. Fasilitasi advokasi kepada TKI berdasarkan hukum dan ketentuan peraturan perundang-undangan di negara penempatan, dan kebiasaan internasional.

Berdasarkan peraturan tersebut dikatakan bahwa pemerintah Indonesia bertanggung jawab atas perlindungan buruh migran pada masa penempatan di luar negeri, dan perwakilan Indonesia (kedutaan dan konsulat) ditugaskan untuk memberikan perlindungan ini yang sejalan dengan standar internasional dan hukum di negara tujuan. Sebagaimana yang diuraikan UNDP (United Nations Development Programme), upaya untuk meningkatkan akses terhadap keadilan terhadap pekerja migran harus terfokus pada upaya untuk menyingkirkan hambatan dalam melakukan akses dengan identifikasi yang jelas. Dalam hal ini, UNDP mencatat bahwa akses terhadap keadilan lebih dari sekedar meningkatkan akses individu ke pengadilan atau memberikan jaminan pendampingan hukum. Hal tersebut untuk memastikan bahwa hasil dari proses hukum dan peradilan berjalan secara adil dan merata, dimana dalam Teori Keadilan oleh Jhon Rawls mengatakan, "Prinsip keadilan yang utama adalah terkait prinsip persamaan dimana setiap orang sama atas kebebasan yang bersifat universal, hakiki dan kompitabel dan ketidaksamaan atas kebutuhan sosial, ekonomi pada diri masing-masing."

Berdasarkan UU No.39 Tahun 2004, bantuan hukum merupakan salah satu Tanggung Jawab perlindungan yang diberikan oleh Kedutaan Besar dan 
Konsulat Jenderal Republik Indonesia (KBRI/KJRI), meski demikian Undang-Undang ini tidak secara spesifik menjelaskan bagaimana Tanggung Jawab ini seharusnya diimplementasikan. Menurut Pasal 17 Peraturan Pemerintah No. 3 Tahun 2013 tentang Perlindungan Tenaga Kerja Indonesia Di Luar Negeri, hal-hal perlindungan terhadap tenaga kerja itu ini mencakup :

1. Pembinaan dan pengawasan, termasuk memantau perwakilan PPTKIS, mitra usaha dan pengguna;

2. Bantuan dan perlindungan kekonsuleran;

3. Pemberian bantuan hukum;

4. Pembelaan atas pemenuhan hak-hak TKI;

5. Perlindungan serta bantuan lainnya yang sesuai dengan ketentuan peraturan perundang-undangan serta hukum dan kebiasaan internasional; dan,

6. Upaya diplomatik.

Berkaitan tentang pemberian nasihat hukum dan pembelaan hukum sangat penting bagi pekerja migran dalam mencari keadilan di luar negeri, dan layanan hukum yang ditetapkan dalam peraturan tahun 2013 cukup lengkap. Hal ini dijelaskan bahwa Access To Justice yang diberikan perwakilan kedutaan dan konsulat Indonesia dalam perlindungan hak-hak pekerja migran di luar negeri, yaitu :

1. Tanggung Jawab Negara terhadap penyediaan bantuan hukum, meliputi : Pemberian mediasi; Pemberian Advokasi ; Pendampingan terhadap TKI yang mengalami masalah hukum (misalnya dalam pertemuan, jadwal pengadilan, layanan pemerintah di negara tujuan); Penanganan masalah TKI yang mengalami tindak kekerasan fisik dan/atau pelecehan seksual; serta Penyediaan Advokat / Pengacara / Ahli Hukum.

2. Tanggung Jawab negara terhadap Pembelaan dan pemenuhan hak-hal tenaga kerja migran Indonesia, meliputi : Memanggil (ke kedutaan) pihak-pihak yang haknya tidak terpenuhi; Melaporkan kepada otoritas yang berwenang; Menuntut pemenuhan hak-hak TKI (sebagaimana yang tercantum dalam Perjanjian Kerja, UU Nasional, UU Ketenagakerjaan di Negara Tujuan, serta UU Internasional); Memperkarakan pihak yang tidak memenuhi hak-hak TKI; Memberikan bantuan terhadap TKI yang dipindahkan ke tempat lain / mejikan lain yang tidak sesuai dengan perjanjian kerja; Melakukan bantuan 
penyelesaian tuntutan dan/atau penyelesaian TKI dengan majikan jasa TKI dan/atau agen tenaga kerja di negara tujuan.

\section{B. Efektifitas Pelayanan Kedutaan dan} Konsulat Terhadap Akses Bantuan Hukum

Migrasi Internasional oleh para pekerja migran akhir-akhir ini menjadi sebuah trend karena maraknya permasalahan mengenai pelanggaran hak pekerja migran, dimana efektifitas terhadap bentuk perlindungan ini belum tercapai. ${ }^{17}$ Menurut Satjipto Rahadjo, berbicara mengenai efektivitas, maka pada hakikatnya sedang dibicarakan mengenai usaha untuk mewujudkan ide-ide tersebut menjadi kenyataan. Efektifitas terkait suatu bentuk pelayanan tidak terlepas dari adanya kesadaran atas pelayanan yang diterima bagi mereka yang menjadi subjek untuk dilayani. Hal ini bila dikaitkan akan pekerja migran maka berhubungan dengan kesadaran mereka terhadap hukum yang melindungi hak-hak mereka.

Kesadaran hukum merupakan kesadaran masyarakat untuk menerima atau menjalankan hukum sesuai dengan tujuan pembentukan hukum yang bersangkutan. Menurut Soerjono

17 Anggaunitakiranantika. 2017. "Migrasi Internasional Pada Wanita di Kabupaten Tulungagung : Sebuah Konstruksi Sosial", Jurnal Sosial Politik, 3(1) : hlm.30.
Soekanto kesadaran hukum merupakan konsepsi abstrak di dalam diri manusia tentang keserasian antara ketertiban dengan ketenteraman yang dikehendaki atau sepantasnya. Kesadaran hukum (legal awareness) memiliki beberapa indikator yakni pengetahuan tentang peraturan-peraturan hukum (law awareness), pengetahuan tentang isi peraturan-peraturan hukum (law acquaintance), sikap terhadap peraturan hukum (legal attitude) dan peri kelakuan hukum (legal behaviour).

Berdasarkan data BNP2TKI, jumlah pengaduan tenaga kerja berdasarkan jenis masalah TKI yang tidak memiliki kelengkapan dokumen, tercatat tahun 2016 sejumlah 133 orang dan tahun 2017 sejumlah 387 orang. Hal tersebut hanya berdasarkan data pengaduan pekerja migran yang diterima oleh BNP2TKI, belum termasuk pengaduan yang diterima oleh lembaga-lembaga lain. Banyaknya pekerja migran yang tidak mengadukan kasusnya karena minimnya akses informasi, terbatasnya pengetahuan, tempat tinggal di daerah terpencil, takut dan lain-lain. ${ }^{18}$

Adapun kasus yang terjadi di Malaysia tahun 2019 terkait

\footnotetext{
${ }^{18}$ Fitri Lestari. 2018. "Pentingnya Pekerja Migran Indonesia memahami dan Memiliki Dokumen". Available from https://www.hukumonline.com/berita/baca/lt5bd1 b1 ff1dd4d/pentingnya-pekerja-migran-indonesiamemahami-dan-memiliki-dokumen-oleh--fitri-lesta ri/. (Accessed February 20, 2020)
} 
dikriminalisasinya delapan pekerja migran Indonesia, dimana dinyarakan oleh Polisi Diraja Malaysia bahwa kedelapan pekerja migran dikriminalisasi karena tidak memiliki dokumen tidak sah. Padahal dalam faktanya bahwa mereka merupakan korban perdagangan orang. Kurangnya pendampingan pihak KBRI terhadap para pekerja migran yang menjadi korban menimbulkan perspektif kinerja KBRI yang sangat pasif dalam mengurusi persoalan yang terjadi terhadap pekerja migran. ${ }^{19}$

Berkaitan dengan kesadaran atas layanan Kedutaan dan Konsulat atas hak-hak mereka, pekerja migran dalam hal ini menganggap lebih akrab terhadap layanan yang diberikan oleh kedutaan bagi mereka. Banyak diantara mereka yang memperoleh informasi sebelum keberangkatan bahwa mereka harus menghubungi kedutaan jika mereka memiliki masalah dengan majikan mereka, dan biasanya mereka diberi nomor telepon kedutaan di negara tujuan. Data dari Kementerian Luar Negeri menunjukkan bahwa sejumlah besar tenaga kerja Indonesia memang mengajukan pengaduan dan keluhan ke kedutaan.

Adapun kasus lain, yaitu terkait para pekerja migran mengetahui tentang kedutaan, tetapi tidak bisa, atau memilih untuk tidak mencari bantuan. Mereka

${ }^{19}$ Sonya Hellen Sinombor. Op.Cit.

154 yang tidak melaporkan ke kedutaan menjelaskan bahwa mereka berada di kota-kota kecil dan secara fisik berada jauh dari perwakilan Indonesia di luar negeri dimana mereka bisa melaporkan pengaduan. Beberapa diantara mereka menyatakan kurang begitu mengetahui tentang lokasi kedutaan dan layanan yang tersedia, dan sebagian lainnya melaporkan adanya persepsi negatif atas bantuan kedutaan.

Mengenai aksesibilitas terhadap layanan Kedutaan dapat diakses oleh buruh migran secara perseorangan, melalui telepon, atau melalui koneksi internet. Terkait aksesibiltas ini, adapun para pekerja migran yang meminta bantuan kedutaan ketika berada di Timur Tengah dengan melalui banyak cara, salah satu pekerja migran telah menelepon kedutaan karena dia memiliki akses ke Internet dan Skype melalui anak majikannya. Bagi buruh migran lainnya, majikan atau teman majikan mengantar pekerja migran tersebut ke kedutaan setelah dia menyatakan keinginan untuk kembali pulang. Salah satu kasus yang terjadi, dimana seorang kerabat majikan membantu pekerja migran tersebut menghubungi kedutaan setelah melihat buruh menangis karena majikan telah mencegahnya pergi pada akhir kontraknya. Sebagian lainnya melarikan diri dan mencegat taksi sendiri, mengandalkan bantuan dari sopir taksi untuk menemukan kedutaan. 
Contoh salah satu kasus yang terjadi lainnya, yaitu berkaitan mengenai urusan dokumen yang dibatasi. Seorang buruh migran menjelaskan bahwa dia ditolak oleh kedutaan setelah melarikan diri karena dia tidak memiliki paspor, meskipun majikannya memegang paspor dan dia tidak bisa memintanya kembali. Seorang ahli dalam kasus buruh migran, yang baru-baru ini menulis sebuah studi tentang peran atase tenaga kerja di Malaysia, mengatakan bahwa kedutaan banyak menolak untuk memberi bantuan buruh migran atau bahkan untuk masuk ke kedutaan karena buruh migran tidak memiliki paspor sehingga dianggap "ilegal”.

Hal ini mencegah kedutaan untuk melakukan fungsi utama sebagai pelindung karena banyak pekerja migran yang pergi ke kedutaan ketika mereka telah melarikan diri dari majikan mereka tanpa dokumen. Para pekerja migran lainnya menyepakati bahwa hal ini umum terjadi, namun Kementerian Luar Negeri menyangkal bahwa para pekerja migran yang bermasalah pernah ditolak.

Berkaitan dengan upaya menciptakan keadilan dan transparansi prosedur, tugas kedutaan dalam hal penanganan kasus pekerja migran tidak diatur secara jelas dalam peraturan atau Panduan Kementerian Luar Negeri Republik Indonesia. Meskipun peraturan menyediakan daftar umum kegiatan yang dapat dilakukan oleh staf kedutaan, daftar ini tidak mencantumkan jadwal, ketentuan etika, hak-hak pekerja migran selama proses atau detail tentang keadaan dimana kasus perlu diselesaikan dan ditutup. Keadilan prosedural dan keprihatinan atas transparansi ini tercermin dalam pengalaman yang dilalui oleh pekerja migran. Pada kebanyakan kasus yang dijelaskan oleh pekerja migran yang menerima bantuan kedutaan yaitu kedutaan menelepon majikan setelah menerima pengaduan, mendengarkan penjelasan dari perspektif majikan dan dinegosiasikan atas nama pekerja migran. Para pekerja migran menjelaskan bahwa anggota staf kedutaan tidak melibatkan mereka dalam komunikasi atau negosiasi yang mereka lakukan dengan majikan, dan buruh migran seringkali dibiarkan tanpa tahu tentang apa yang terjadi selama berlangsungnya interaksi tersebut.

Berkaitan dengan adanya ketersediaan bantuan hukum, meskipun undang-undang dan peraturan memberikan bantuan hukum dan pendampingan hukum melalui kedutaan atau konsulat, banyak dari pekerja migran yang merasa tidak menerima bantuan hukum dari kedutaan ini. Hal tersebut menjadi alasan kurang efektifnya layanan bantuan yang diberikan oleh kedutaan dan konsulat bagi pekerja migran yaitu : 
1. Jauhnya akses ke kedutaan atau konsulat perwakilan;

2. Adanya pembatasan akses terhadap dokumentasi tanpa mencari tahun sebab akibatnya ;

3. Tidak mengetahui adanya bantuan hukum dari kedutaan dan konsulat;

4. Pekerja migran tidak merasa ada bantuan hukum yang diterima oleh mereka karena kedutaan hanya mendengarkan dalam perspektif majikan;

5. Kurangnya kehadiran tanaga ahli hukum / pengacara yang membantu menangani kasus mereka;

Mengingat begitu banyaknya pekerja migran yang tidak menyadari mekanisme yang ada saat mereka kembali, atau tidak memiliki dokumen-dokumen penting ini, akan tampak bahwa kedutaan masih menitikberatkan pada perlindungan dan penyelesaian kasus, dan kurang terfokus pada, atau memberikan perlengkapan untuk menangani, akses jangka panjang dan berarti terhadap keadilan bagi para pekerja migran. Hal yang lebih sering terjadi adalah terkait adanya pelanggaran hukum, dimana para pekerja migran kesulitan dalam mencari bantuan hukum. Dalam perbuatan melanggar hukum diupayakan ada pendampingan oleh lawyer / ahli hukum kepada para pekerja migran dari setiap proses pengadilan yang dilaksanakan baik. ${ }^{20}$

\section{Penutup}

Berdasarkan

pembahasan

penelitian ini, adanya beberapa kasus yang dihadapi pekerja migran Indonesia di luar negeri mengalami kesulitan untuk mendapatkan akses keadilan terhadap pemenuhan hak-haknya. Kurangnya peran aktif pihak Kedutaan dan Konsulat dalam memenuhi hak-hak pekerja migran menjadi catatan penting masih belum efektifnya perlindungan dan pemenuhan yang dilakukan pemerintah Indonesia ini.

Terkait bantuan dari Kedutaan dan Konsulat di negara tujuan pekerja migran yang signifikan haruslah relevan sesuai prosedur standar bagi penyelesaian perselisihan antara pihak pekerja migran dan majikan, termasuk dalamn hak-hak pekerja migran terhadap informasi dan turut berpartisipasi dalam proses tersebut untuk menjamin transparansi dan keadilan sebagaimana yang tercantum dalam Peraturan Pemerintah No. 3 Tahun 2013.

Kedutaan dan Konsulat harus menetapkan prosedur untuk memastikan bahwa buruh migran yang tidak memiliki paspor atau dokumentasi lainnya

\footnotetext{
20 Hidayat. 2017. "Perlindungan Hak Tenaga Kerja Indonesia Di Taiwan dan Malaysia Dalam Perspektif Hak Asasi Manusia", Jurnal HAM, 8(2) : hlm.110.
} 
menerima bantuan dari perwakilan Indonesia ini, dimana memberikan pelayanan untuk memfasilitasi penerimaan dokumen pekerja migran kembali yang diperlukan untuk mengajukan klaim, baik di negara tempat bekerja maupun setelah kepulangan mereka ke Indonesia. Serta hal yang penting adalah pemerintah harus menentukan kriteria dan proses yang lebih jelas untuk menilai kualitas agen tenaga kerja mitra dan majikan komersial berdasarkan perlakuan mereka yang berkelanjutan terhadap buruh migran.

\section{Bibliografi}

\section{Buku-Buku}

Boer Mauna. 2000. Hukum Internasional : Pengertian, Peranan, dan Fungsi Dalam Era Dinamika Global. Bandung : Alumni.

Jhonny Ibrahim. 2006. Teori dan Metodologi Penelitian Hukum Normatif. Malang : Bayumedia Publishing.

Lili Rasjidi \& Wysa Putra. 2003. Hukum

Sebagai Suatu Sistem. Bandung : Remaja Rusdakarya.

\section{Artikel Jurnal :}

Aga Natalis dan Budi Ispriyarso. 2018. "Politik Hukum Perlindungan Pekerja Migran Perempuan di Indonesia", Pandecta Research Law Journal, 13(2) : 109-123.
Anggaunitakiranantika. 2017. "Migrasi Internasional Pada Wanita di Kabupaten Tulungagung : Sebuah Konstruksi Sosial", Jurnal Sosial Politik, 3(1) : 26-41.

Arpangi. 2016. "Perlindungan Hukum Terhadap tenaga Kerja Indonesia Di Luar Negeri”, Jurnal Pembaharuan Hukum, 3(1) : 149-156.

Haning Romdiati. 2012. "Migrasi Tenaga Kerja Indonesia Dari Kabupaten Tulungagung : Kecenderungan dan Arah Migrasi, serta Remitansi", Jurnal Kependudukan Indonesia, (7(2) : 27-5.

Hidayat. 2017. "Perlindungan Hak Tenaga Kerja Indonesia Di Taiwan dan Malaysia Dalam Perspektif Hak Asasi Manusia", Jurnal HAM, 8(2) : 105-115.

Lalu Husni. 2011. "Perlindungan Hukum Terhadap Tenaga Kerja Migran Indonesia Di Luar Negeri", Mimbar Hukum. 23(1) :150-167, DOI.

Peni Setyorini. 2010. "Perlindungan Tenaga Kerja Indonesia (TKI) Di Luar Negeri Oleh Perwakilan Republik Indonesia”, Masalah-Masalah Hukum, 39(1) : 65-77.

Rahadi Wasi Bintoro, dkk. 2008. "Implementasi UU No.13 Tahun 2003 Tentang Ketenagakerjaan Bagi Tenaga Kerja Perempuan di 
Kabupaten Purbalingga", Jurnal Dinamika Hukum, 8(3) : 231-240.

Riri Anggriani. (2017). "Perlindungan Hukum Bagi Irregular Migrant Workers Indoneisa Di Kawasan Asia Tenggara (Dalam perspektif Hukum HAM Internasional)", Jurnal Yuridika. 32(2) : 310-335.

Rizky Dian Bareta \& Budi Ispriyarso. 2018. "Politik Hukum Perlindungan tenaga Kerja Indonesia Fase Purna Bekerja", Kanun Jurnal IImu Hukum. 20(1) : 163-181.

Syamsul Hadi. 2008. "Sekuritisasi dan Upaya Peningkatan Perlindungan Terhadap Tenaga Kerja Indonesia", Jurnal Hukum Internasional Labour Law, 5(4) :741-765.

Tri Lisiani Prihatinah, dkk 2012. "Kendala Perlindungan Hukum Terhadap Buruh Migran di Kabupaten Cilacap", Jurnal Dinamika Hukum, 12(2): 312-320.

Yuni Sudarwati. 2014. "Upaya Indonesia Menghadapi Migrasi Tenaga Kerja Dalam Komunitas Ekonomi Asean (KEA) 2015", Jurnal Ekonomi \& Kebijakan Publilk, 5(1) : 15-28.

\section{Sumber Hukum Indonesia :}

Undang-Undang Dasar Negara Republik Indonesia Tahun 1945.

Undang-Undang No.39 Tahun 1999 tentang Hak Asasi Manusia (Lembaran Negara Republik
Indonesia Tahun 1999 Nomor 138, Tambahan Lembaran Negara Republik Indonesia Nomor 3872) Undang-Undang No.39 Tahun 2004 tentang Penempatan dan Perlindungan Tenaga Kerja Indonesia di Luar Negeri (Lembaran Negara Republik Indonesia Tahun 2004 Nomor 133) Undang-Undang No.18 Tahun 2017 tentang Perlindungan Pekerja Migran Indonesia (Lembaran Negara Republik Indonesia Tahun 2oi7 Nomor 242, Tambahan Lembaran Negara Republik Indonesia Nomor 6141)

Undang-Undang Nomor 6 Tahun 2012 tentang Pengesahan International Convention on The Protection of The Rights of All Migrant Workers and Members of Their Families (Konvensi Internasional Mengenai Perlindungan Hak-Hak Seluruh Pekerja Migran dan Anggota Keluarganya) (Lembaran Negara Republik Indonesia Tahun 2012 Nomor 115, Tambahan Lembaran Negara Republik Indonesia Nomor 5314)

Instruksi Presiden No.6 Tahun 2006 tentang Kebijakan Reformasi Sistem Penempatan dan Perlindungan Tenaga Kerja Indonesia.

Peraturan Pemerintah No. 3 Tahun 2013 tentang Perlindungan Tenaga 
Kerja Indonesia di Luar Negeri.

\section{Internet :}

\section{Sumber Hukum Internasional /} Perjanjian Internasional :

International Convention on the

Protection oof the Rights of All

Migrant Workers and Members of

Their Families 1990

ILO Convention C143 - Migrant Workers

(Supplementary

Provision)

Convention 1975 / Convention

Concerning Migrations in Abusive

Conditions and the Promotion of

Equality of Opportunity and

Treatment of Migrant Workers,

ILO Convention C097 - Migrant for

Employment Convention (Revised)

1947 / Convention Concerning

Migration for Employment (Revised 1949).
Fitri Lestari. 2018. "Pentingnya Pekerja Migran Indonesia memahami dan Memiliki Dokumen". Available from:

https://www.hukumonline.com/berit a/baca/lt5bd1b1ff1dd4d/pentingny a-pekerja-migran-indonesia-mema hami-dan-memiliki-dokumen-oleh-fitri-lestari/. (Accessed February 20, 2020).

Sonya Hellen Sinombor, 2020, "Kedutaan Besar RI Diminta Pro-Aktif Lindungi Buruh Migran", Available from: https://bebas.kompas.id/baca/hum aniora/dikbud/2020/01/23/kedutaa n-besar-ri-diminta-pro-aktif-lindung i-buruh-migran/.

(Accessed February 20, 2020). 